\title{
Livelihood Status of Tribal People Practicing Shifting (Jhum) Cultivation in Tripura State of North-East India
}

\author{
Jayasree Datta*, N.R. Gangadharappa and G.S. Biradar \\ Department of Agricultural Extension \\ Ghandi Krishi Vignan Kendra, University of Agricultural Sciences \\ Bangalore, India
}

\begin{abstract}
Jhum or shifting cultivation is the dominant land-use practice of northeastern region of India. Jhum cultivation systems are generally productive, making efficient use of resources, ensuring ecological sustainability and food security, thus providing a social safety net for local communities. It is an ecologically and economically viable system of agriculture as long as population densities are low and Jhum cycles (fallow period) are long enough to maintain ecological balance. Population explosion and increased demand for cultivable land with the emergence of new generation of youth cultivators have resulted in reduction of the cultivation cycle. This has seriously affected the local livelihoods and environmental sustainability in many pockets of the region. This study was conducted during 2012-13 in Gomati district of Tripura state in North-East India to understand the livelihood status of tribal people practicing Jhum. Data were collected using structured interview scheduled for 140 tribal farmers. The results revealed that the highest proportion (39.3\%) of tribal farmers have low livelihood status followed by medium (36.4\%) and high (24.3\%) livelihood status. Education, family size, number of family members involved in Jhum, area under Jhum, annual income, fallow period, livestock possession, material possession, and extension participation had positive significant relationships with the livelihood status of the study sample and thus, could be manipulated to improve the livelihood status of tribal people.
\end{abstract}

Keywords: Jhum, livelihood, shifting cultivation, tribal people

\section{INTRODUCTION}

The important problem faced by tribal communities in India is how to earn and sustain livelihoods. There are varieties of livelihood practices by the tribal communities in different parts of India and elsewhere, such as the hunter-gatherers, pastoralist and shifting cultivators who live in different environments. Many changes have been taking place with regard to land use, access, control and utilization of their resource and these changes in turn have largely affected the sustainable livelihoods of the people without emphasizing sustainable replacement (Shivaprasad \& Eswarappa, 2007).

It is recognized that shifting cultivation is the key to the livelihoods of many ethnic, indigenous and tribal groups in the tropical and sub-tropical highlands of Asia and Africa as well as Latin America (Andersen et al, 2008). Shifting cultivation or Jhum in Northeast India is a widely practiced form of agriculture in the upland areas of Northeast India and generally

* Corresponding author: dattajayasree3@gmail.com 
productive, make efficient use of resources and have supported large populations. Jhum cultivation contributes $85 \%$ of the total cultivation in Northeast India. About 26,000 households practice shifting cultivation (Jhum) every year and nearly 143,000 people depend on Jhum for subsistence (Shoaib, 2000). It has evolved as a traditional practice and is an institutionalized resource management mechanism ensuring ecological sustainability and food security thus providing a social safety net for local communities (Andersen et al., 2008).

The practice of Jhum is not, merely exercised by the tribals for their sustenance, but a traditional method of earning a livelihood, a traditional farming system that uses local product and techniques, has rooted in the past, has evolved to their present stage as a result of the interaction of the cultural and environmental condition of the region and is deeply embedded in the tribal psyche (Gupta, 2005). Chhauchhuak (2004) reported that crop mix of perennial and season crops in Jhum cultivation allows phased harvesting ensuring food security throughout the year and also provide needed diversity for nutrition and food preferences. Sarangi \& Singh (2007) observed that pseudo cereals, small millets, indigenous pulses, oil seeds and many forest plants form an important component of food source for the tribal population. Species have been used as life sustaining food as well as medicines from time immemorial. Akinnifesi et al. (2008) reported that the availability of Non Timber Forest Products serves as an important gap-filler when food stocks are low and also as a source of income. For example, the collection of indigenous fruits contributes between 5.5 and $6.5 \%$ to the total household income in the rural communities of Southern Africa. Nath et al. (2005) reported that tribal people of the Chittagong Hill Tract of Bangladesh still practice Jhum as a principal source of livelihood. But a rapid rise in population (both endemic and migration influx of plains people), the construction of development infrastructure (e.g. hydroelectric projects), and government policies on expansion of reserve and protected forests has made the Jhum vulnerable. Belsky \& Siebert (2003) stated that farmers in the Chittagong Hill Tract who live mostly in inaccessible hilly areas and are deprived of all humanitarian services and facilities are forced to practice traditional Jhum. In order to maintain their livelihoods, there is need to balance food and income generation, and a combination of onand off-farm enterprises helps to maintain the balance. Yeo-Chang (2009) found that in South Korea, forest income arises more from non-timber forest products (NTFPs) and forest ecosystems services than from timber. The mere existence of forest resources and related cultural heritages is not enough for local communities to obtain income from forest land. Proper arrangements for local communities in accessing the forest resources and knowledge of making use of the resources is required to make the relationship constructive for people's livelihood. Mertz (2002) stated that although introduced changes may indeed be very valuable for local livelihoods and environment, there is little evidence that shifting cultivation will ever reach a stage of environmental degradation and low productivity, which could be considered a "breakdown" of the system.

The practice of Jhum involves site selection, slash and burn, followed by mixed cropping for a year or two and fallowing for certain years for recuperation of the land. Jhum cultivation is changing rapidly in many areas, partly because of population pressure and partly because livelihood strategies are diversified to include permanent cultivation of cash crops and offfarm work (Eder, 2003). Population explosion and emergence of new generation of youth cultivators' increasing demand for cultivable land has resulted in reduction of the cycle of cultivation from 10-15 years to 2-3 years. This is seriously impacting the local livelihoods and environmental sustainability in many pockets of the region. Keeping the above aspect in view, this study was conducted with the objective to know the livelihood status of tribal people practicing Jhum in Tripura. 


\section{METHODOLOGY}

Locale of the study: The research was conducted in Gomati district of Tripura state in India. Gomati district consists of three sub-divisions. They are Udaipur with three blocks, and Amarpur and Karbuk with two blocks each. From each of these seven blocks of Gomati district two villages were selected purposively considering the maximum number of people practicing Jhum cultivation. From each of the selected fourteen villages 10 farmers were selected randomly, thus making the total of 140 respondents for the study.

Table 1 Selection of sample from the four districts of Tripura State (India during the year 2012-13)

\begin{tabular}{|c|c|c|c|c|c|}
\hline State & District & Subdivision & Block & Villages & Sample size \\
\hline \multirow{7}{*}{ Tripura } & \multirow{7}{*}{ Gomati } & \multirow{3}{*}{ Udaipur } & Matabari & 2 & 20 \\
\hline & & & Kakrabon & 2 & 20 \\
\hline & & & Killa & 2 & 20 \\
\hline & & \multirow{2}{*}{ Amarpur } & Amarpur & 2 & 20 \\
\hline & & & Ampi & 2 & 20 \\
\hline & & \multirow{2}{*}{ Karbuk } & Karbuk & 2 & 20 \\
\hline & & & Silachari & 2 & 20 \\
\hline & & & Total & & 140 \\
\hline
\end{tabular}

\section{Measurement of the variables}

Livelihood status: Livelihood status is operationalised as status of tribal farmers with reference to capabilities, assets, activities and coping strategies to overcome stress for Jhum cultivation to ensure livelihood security.

Based on review of literature four component of livelihood security were selected to know the livelihood status of tribal people. Responses were taken under three categories viz. less satisfied, satisfied, highly satisfied and given a score of 1,2, and 3 respectively.

Based on total score of the respondents in the overall Jhum cultivation practice, the respondents were classified into three categories viz. low $(<$ Mean $-1 / 2 \mathrm{SD})$, medium (=Mean $\pm 1 / 2$ SD), high (>mean $+1 / 2$ SD). Personal interview method was employed for data collection. Correlation analysis was used to find the relationship between livelihood status of tribal farmers and their personal, socio-economic, psychological and communication characteristics. Regression analysis was used to know the contribution of personal, socioeconomic, psychological, communication characteristics of the farmers on livelihood status of tribal farmers. 


\section{RESULTS AND DISCUSSION}

\section{The livelihood status of the tribal people}

The assets, activities and capabilities which provide livelihood status to the tribal people are size of land, selling of products of Jhum, their ability to call on friends or neighbours for help at times of need, community support, quality of labour which is available at household level, skills of the family member, their physical fitness to do hard work, their access to common property resources and also benefit from the common property resources. The details of their livelihood status are given below.

\section{A. Assets}

I. Natural assets: From Table 2 it can be observed that $53.6 \%$ of the tribal people were satisfied and $3.6 \%$ were highly satisfied with size of land. This is because they were freely accessible to more area to increase their Jhuming; $72.9 \%$ farmers are less satisfied with livestock units and only $27.1 \%$ of them were satisfied because they did not have well established structure for livestock units. Generally they keep their livestock in their house yard as they have less number of livestock. Very few farmers (16.4\%) are satisfied with forest wealth and which provides additional income (timber, woods).

II. Social assets: Majority of the farmers $(84.3 \%)$ were highly satisfied with their ability to call on friends because all the tribal people practicing Jhum in the village live and work together and no tribal farmers pay labour charges for Jhuming. $88.6 \%$ of farmers are highly satisfied with community support during crisis situation because all of them come together for each other's help and they borrow money from their own community people during crisis period. Only $15.7 \%$ of tribal people were satisfied with right or claim that derives from membership of a group (NTFPs Honey bee groups), because there were very few Jhumia who were members of groups. Moreover, in the tribal villages there are very few Self Help groups (SHGs) that existed.

III. Human assets: All of them were satisfied with quality of labour at household level and more than three fourth of them $(77.9 \%)$ were less satisfied with education of family member. The reason might be due to illiteracy and majority of them used to engage in Jhuming activities; about nearly three fourth $(72.1 \%)$ of tribal people are highly satisfied with health and physical fitness to do hard work, as Jhum require more hard work in hilly slopes.

IV. Physical assets: More than half $(52.9 \%)$ of tribal farmers are less satisfied with infrastructure facility (roads, electricity, improved equipment and housing). This is due to poor infrastructure facility available in the hilly regions.

V. Financial asset: Most of the tribal people (72.9\%) are less satisfied with stocks of money or other saving because of less annual income as most of them with belong to small and marginal farmer category; $86.4 \%$ of the farmers are satisfied with the access to credit because of the self financed programmes operating in the area through self help groups.

B. Activities: From the results it can be inferred that only $6.4 \%$ of tribal people are highly satisfied and $54.3 \%$ of them are satisfied with returns from selling of Jhum products- NTFPs (Non timber forest products) like forest based (honey, fruits) and non forest based (paddy). The reason is that most of them are small and marginal farmers and all of them practice almost organic agriculture, so the yield/output per unit area (productivity) is also less. Hence, 
they are not satisfied with their returns from Jhum; $82.1 \%$ of farmers are less satisfied with returns from forest and non-timber forest products because of restrictions from the Forest Department, also $85.0 \%$ of the farmers are less satisfied with return from weaving, tailoring because they don't have proper marketing network.

Table 2. Analysis of livelihood status of the tribal people practicing Jhum (multiple responses) $\quad(n=140)$

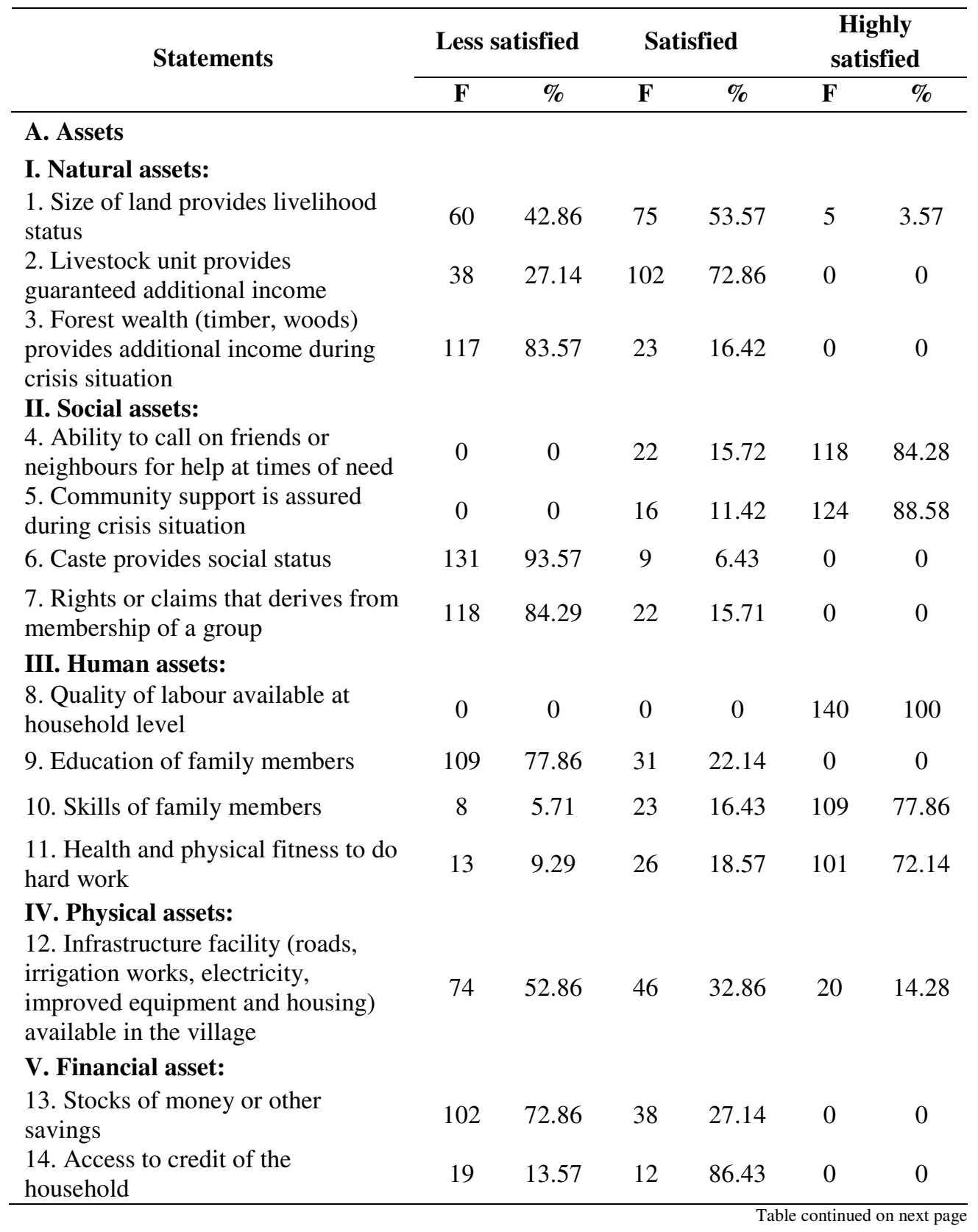




\begin{tabular}{|c|c|c|c|c|c|c|}
\hline \multirow{2}{*}{ Statements } & \multicolumn{2}{|c|}{ Less satisfied } & \multicolumn{2}{|c|}{ Satisfied } & \multicolumn{2}{|c|}{$\begin{array}{c}\text { Highly } \\
\text { satisfied }\end{array}$} \\
\hline & $\mathbf{F}$ & $\%$ & $\mathbf{F}$ & & $\mathbf{F}$ & $\%$ \\
\hline $\begin{array}{l}\text { 15. Returns from selling Jhum } \\
\text { products gives satisfactory income }\end{array}$ & 55 & 39.28 & 76 & 54.29 & 9 & 6.43 \\
\hline $\begin{array}{l}\text { 16. Land is cultivated for fully } \\
\text { growing of crops }\end{array}$ & 0 & 0 & 0 & 0 & 140 & 0 \\
\hline $\begin{array}{l}\text { 17. Family members are engaged in } \\
\text { Jhuming and rearing livestock }\end{array}$ & 74 & 52.85 & 66 & 47.14 & 0 & 0 \\
\hline $\begin{array}{l}18 . \text { Benefit from common property } \\
\text { resources }\end{array}$ & 0 & 0 & 0 & 0 & 140 & 100 \\
\hline $\begin{array}{l}\text { 19. Income from employment of } \\
\text { family members in Forest } \\
\text { Department }\end{array}$ & 140 & 100 & 0 & 0 & 0 & 0 \\
\hline $\begin{array}{l}\text { 20. Returns from forest and non- } \\
\text { timber forest products give } \\
\text { satisfactory income }\end{array}$ & 115 & 82.14 & 25 & 17.86 & 0 & 0 \\
\hline $\begin{array}{l}\text { 21. Return from weaving, tailoring } \\
\text { gives good satisfaction }\end{array}$ & 119 & 85.00 & 21 & 15.00 & 0 & 0 \\
\hline C. Capabilities & & & & & & \\
\hline $\begin{array}{l}\text { 22. Have sufficient access to } \\
\text { common property resources }\end{array}$ & 0 & 0 & 0 & 0 & 140 & 100 \\
\hline $\begin{array}{l}\text { 23. Have extended family rights } \\
\text { such as rights to live with a family } \\
\text { member in rough time }\end{array}$ & 140 & 100 & 0 & 0 & 0 & 0 \\
\hline $\begin{array}{l}\text { 24. Assistance given by church or } \\
\text { temple group when family member } \\
\text { dies or falls sick }\end{array}$ & 120 & 85.71 & 20 & 14.29 & 0 & 0 \\
\hline D. Coping strategies from stress & & & & & & \\
\hline $\begin{array}{l}\text { 25. Working under Forest } \\
\text { Department as labour helps in stress } \\
\text { condition }\end{array}$ & 140 & 100 & 0 & 0 & 0 & 0 \\
\hline $\begin{array}{l}\text { 26. Preparation and selling of } \\
\text { bamboo made products gives } \\
\text { income under stress condition }\end{array}$ & 115 & 82.14 & 25 & 17.86 & 0 & 0 \\
\hline $\begin{array}{l}\text { 27. Depending on specialized } \\
\text { occupation like weaving, tailoring } \\
\text { helps in stress condition }\end{array}$ & 119 & 85.00 & 21 & 15.00 & 0 & 0 \\
\hline
\end{tabular}


C. Capabilities: All the tribal people were highly satisfied with their access to common property resources because they are freely accessible to more areas and they have enough rights to cultivate the crops in hilly slopes and forest lands for bonafied purpose. All of them are highly satisfied with the extended family rights because the entire family member work together in Jhum and also they spend their daily life together in rough time. Only few tribal people were satisfied with assistance given by church or temple group when family member dies or fall sick because rarely they used to get assistance.

D. Coping strategies from stress: All the tribal people are less satisfied to work as labour in the Forest Department because they seldom get a chance to work as labour, $82.14 \%$ farmers are less satisfied with preparation and selling of bamboo made products because of lack of availability of bamboo and also restrictions from the Forest Department, $85 \%$ farmers are less satisfied with specialized occupation like weaving, tailoring because of market problem.

These findings of the study are consistence with Maslow's Hierarchy of Needs (1943). These needs are sequential starting with the most basic needs and building up to more complex. The "Hierarchy of Needs" is physiological needs (food, water and air), Safety needs (security, stability, and freedom from fear or threat), social needs (friendship, affection, acceptance, and interaction with others), Esteem needs (personal feelings of achievement or self-esteem and need for recognition or respect from others), Self-actualization (selffulfilment or realization of one's potential) become everything that one is capable of becoming. All these are for their sustenance. It is the fact that tribal people are living in the remote area who are deprived the development phase for years. Therefore the tribal people were not exposed to modernization which eventually made them to live with what they had. Recently, interventions are introduced through many programmes/ schemes to uplift them and to bring them to the mainstream of development. The interventions are in transition phase and the tribal people can move forward after achieving hierarchy of needs as given by Maslow in a phase manner.

Overall livelihood status of tribal people: It is observed that $39.3 \%$ tribal people practicing Jhum had low livelihood status followed by $36.4 \%$ had medium livelihood status and $24.3 \%$ had high livelihood status. The reason might be as most of the farmers are marginal and small farmers, soil fertility of Jhum land is decreasing and also almost all of them are fully dependent on biomass generated in the field for the use as fertilizer (organic agriculture), the productivity is less hence income from Jhum also less. So, most of the Jhumia's socioeconomic condition is low or medium. Hence, majority of them belongs to low to medium livelihood status category. 
Table 3. Correlation between livelihood status of the tribal people practicing Jhum with personal, socioeconomic, psychological and communication characteristics of farmers $(n=140)$

\begin{tabular}{|c|l|c|}
\hline Sl. No. & Independent variables & $\begin{array}{c}\text { Correlation co- } \\
\text { efficient }(\mathbf{r})\end{array}$ \\
\hline 1 & Age & $-0.122^{\mathrm{NS}}$ \\
\hline 2 & Education & $0.323^{* *}$ \\
\hline 3 & Family size & $0.194^{*}$ \\
\hline 4 & No. of family members involved in Jhum & $0.328^{* *}$ \\
\hline 5 & Area under Jhum & $0.702^{* *}$ \\
\hline 6 & Annual income & $0.664^{* *}$ \\
\hline 7 & Fallow period & $0.177^{*}$ \\
\hline 8 & Cosmopoliteness & $0.115^{\mathrm{NS}}$ \\
\hline 9 & Livestock possession & $0.196^{*}$ \\
\hline 10 & Material possession & $0.216^{* *}$ \\
\hline 11 & Credit orientation & $0.073^{\mathrm{NS}}$ \\
\hline 12 & Extension participation & $0.193^{*}$ \\
\hline 13 & Mass media participation & $-0.045^{\mathrm{NS}}$ \\
\hline
\end{tabular}

** Significant at 0.01 level, * Significant at 0.05 level, NS Non-Significant

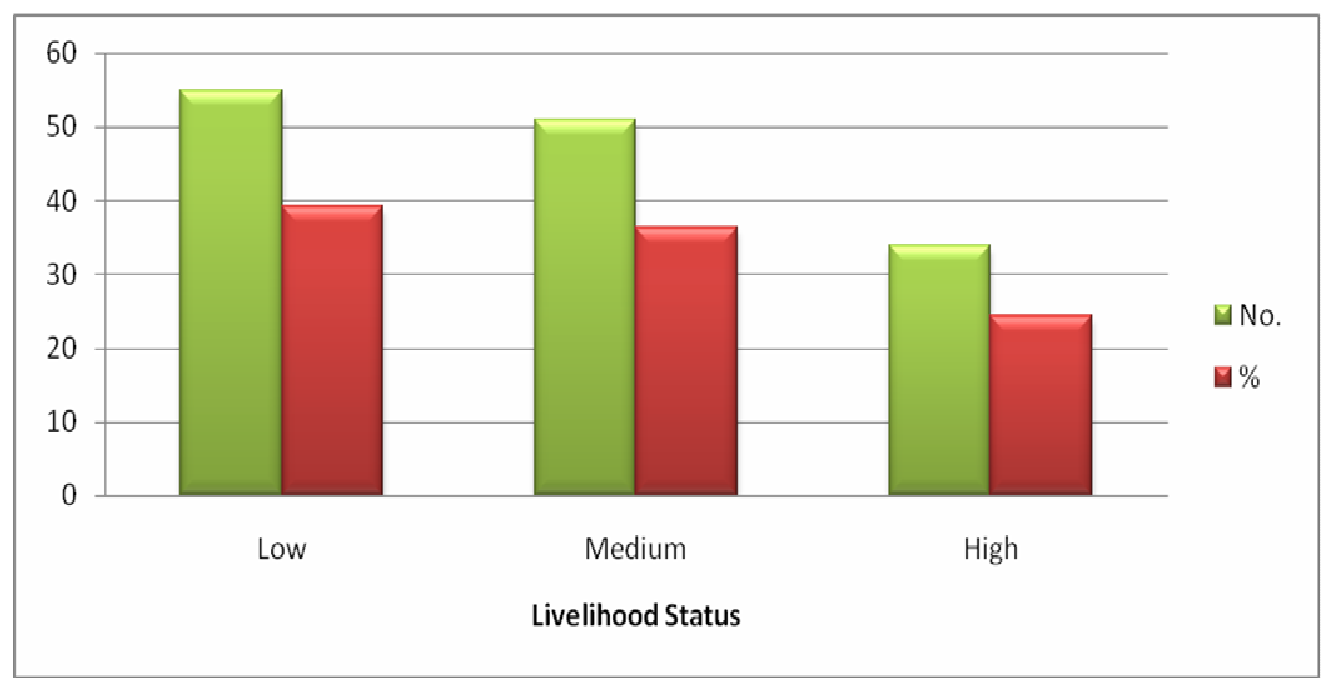

Fig 1. Overall livelihood status of tribal people

The data presented in Table 3 show that education, numbers of family member involved in Jhum, area under Jhum, annual income and material possession had positive significant relationship with livelihood status at one percent level of significant. Whereas family size, fallow period, livestock possession and extension participation had positive and significant relationship with livelihood status at five percent level of significant. Other variable such as age, cosmopoliteness, credit orientation, mass media participation had non-significant relationship with livelihood status of tribal people. 
Education was found to be positively significantly related with livelihood status of tribal people. Education plays an important role in developing searching capacity for livelihood status. The tribal people also respect and give importance to the people who are educated among themselves and livelihood status in the society will also be more. The reason is that educated tribal farmers will have more knowledge about new technologies which gives better returns.

Area under Jhum and annual income were also found to be positively and significantly related with livelihood status of farmers. If area under Jhum is more, income will also be more and level of income is also one of the important parameter in measuring the livelihood status of farmer in the village.

Fallow period also was found to be positively significant with livelihood status of farmers. As the fallow period increases, the soil fertility will also increases which will contribute to higher productivity of crop. Hence it will influence in livelihood status, through productivity level.

The result revealed that there was a positive and significant relationship of cosmopoliteness with livelihood status. The possible reason for this might be that the tribal people with greater cosmopoliteness will have greater contact with the outside world, which might have broadened the mental horizon of farmers. Thus it will facilitate to increase their livelihood status.

Material Possession was also found to be positively significantly related with livelihood status of farmers. If farmer possess more number of materials, they will acquire more comforts in their house which naturally will influence in their livelihood status.

Extension participation was also found to be positively and significantly related with livelihood status of farmers. If extension participation is more farmers will have more information about new sustainable Jhum technologies which will help them to get more yield and income from Jhum.

Table 4. Contribution of independent variables on livelihood status of tribal people practicing Jhum $(n=140)$

\begin{tabular}{|c|l|c|c|c|}
\hline $\begin{array}{l}\text { Sl. } \\
\text { No. }\end{array}$ & \multicolumn{1}{|c|}{ Independent variables } & $\begin{array}{c}\text { Regression } \\
\text { co-efficient }(\boldsymbol{\beta})\end{array}$ & Std. Error & 't' value \\
\hline 1 & Age & -0.047 & 0.019 & $-0.714^{\mathrm{NS}}$ \\
\hline 2 & Family size & -0.140 & 0.382 & $-1.829^{\mathrm{NS}}$ \\
\hline 3 & $\begin{array}{l}\text { Number of family members } \\
\text { involved in Jhum }\end{array}$ & 0.151 & 0.415 & $2.202^{*}$ \\
\hline 4 & Area under Jhum & 0.703 & 0.313 & $9.520^{* *}$ \\
\hline 5 & Fallow period & 0.101 & 0.247 & $1.644^{\mathrm{NS}}$ \\
\hline 6 & Cosmopoliteness & -0.015 & 0.287 & $-0.210^{\mathrm{NS}}$ \\
\hline 7 & Livestock possession & 0.095 & 0.031 & $1.400^{\mathrm{NS}}$ \\
\hline 8 & Material possession & 0.037 & 0.185 & $0.552^{\mathrm{NS}}$ \\
\hline 9 & Credit orientation & -0.044 & 0.214 & $-0.651^{\mathrm{NS}}$ \\
\hline 10 & Extension participation & -0.027 & 0.219 & $-0.380^{\mathrm{NS}}$ \\
\hline 11 & Mass media participation & -0.008 & 0.290 & $-0.116^{\mathrm{NS}}$ \\
\hline
\end{tabular}

** Significant at 0.01 level, * Significant at 0.05 level, NS Non-Significant 
It is observed from Table 4 that there is $54.2 \%$ variation in livelihood status of tribal people due to the identified independent variables for the research study. Area under Jhum and number of family members involved in Jhum had positive significant relationship with livelihood status. According to ' $t$ ' test criterion, these two variables had contributed most for the variation in livelihood status of tribal people because their main occupation is Jhuming, so area under Jhum and number of family members involved in Jhum will facilitate in increasing their livelihood status.

\section{CONCLUSION}

From the results of the research it can be concluded that majority of the farmers' livelihood status was low followed by medium livelihood status and high livelihood status. Education, number of family members involved in Jhum, area under Jhum, annual income and material possession had positive significant relationship with livelihood status at one percent level of significant, whereas family size, fallow period, livestock possession and extension participation had positive significant relationship with livelihood status at five percent level of significant. Other characteristics had non-significant relationship with livelihood status of tribal people. Area under Jhum and numbers of family member involved in Jhum had contributed most for variation in livelihood status of tribal people.

\section{Recommendations}

1. The members' tribal family need to be educated to enhance their capability to search for knowledge which facilitate to their livelihood status.

2. The development agencies must give priority to "Farming System Approach" to avoid further encroachment of forest land as area under Jhum is related to improving the livelihood status.

3. Holistic approach is necessary to bring all round development among the tribal's and to check further degradation of natural resources.

\section{REFERENCE}

Akinnifesi, F.K, Sileshi, G., Ajayi, O.C., Chirwa, P.W., Mngomba, S., Chakeredza, S. and Nyoka, B.I. (2008). Domestication and Conservation of Indigenous Miombo Fruit Trees for Improving Rural Livelihoods in Southern Africa, Tropical Conservancy, pp. 72-74.

Andersen, K.E., Sophorn, S. and Thornberry, F. (2008). Development of a sub-decree on shifting cultivation under Article 37 of the Forestry Law (2002), Cambodia, International Labor Organisation, Support to Indigenous People Project in Cambodia.

Belsky, J.M., and Siebert, S.F. (2003). Cultivating Cacao: Implications of sun-grown cacao on local food security and environmental sustainability. Agriculture and Human Values, 20, 277-285.

Chhauchhuak, L. (2004) Jhum Works, Shillong Declares on Jhum: Benefits Jhum cultivation. Down to earth, $15^{\text {th }}$ Nov. 2004. 
Eder, J.F. (2003) Land use and economic change in the post-frontier upland Philippines, Land Degradation \& Development, 17(2), 79-101.

Gupta, V. (2005) Jhum cultivation practices of the Bangnis (Nishis) of Arunachal Pradesh, Indian Journal of Traditional Knowledge, 4(1), 47-56.

Maslow, A.H. (1943) A Theory of Human Motivation, Psychological Review, 50, 370-396.

Mertz, O. (2002) The relationship between fallow length and crop yields in shifting cultivation: a rethinking. Agro-forestry Systems, 55, 149-159.

Nath, T.K., Inoue, M. and Chakma, S. (2005) Shifting Cultivation (Jhum) in the Chittagong Hill Tracts, Bangladesh: Examining its Sustainability, Rural Livelihood and Policy Implications, International Journal of Agricultural Sustainability, 3(2), 130-142.

Sarangi, S.K., De, L.C. and Singh Ramesh. (2007) Indegenous Life Supporting Plants of Arunachal Pradesh, ICAR Research Bulletin No. 52, ICAR Research Complex for NEH Region, Umiam, Megahlaya, India.

Shoaib, J.U. (2000). Development of Sustainable Cultivation Practices for Minimizing Soil Erosion on Hill Slope, Bangladesh Agricultural Research Council and Soil Resources Development Institute, Dhaka, Bangladesh.

Shivaprasad, R. and Eswarappa, K. (2007). 'Tribal livelihood in a limbo: Changing tribenature relationship in South Asia' in at the crossroads: South Asia research, policy and development in global world, pp: 69-78.

Yeo-Chang, Y. (2009). Use of forest resources, traditional forest-related knowledge and livelihood of forest dependent communities: Cases in South Korea, Forest Ecology and Management 257, 2027-2034. 